DOI: $10.17951 /$ lrp. 2017.36.4.91

\author{
ElŻBieta Marek
}

Akademia Ignatianum w Krakowie

ElżBieta Salata

Uniwersytet Technologiczno-Humanistyczny w Radomiu

\title{
PEDAGOGICZNA INTERPRETACJA ZAJĘĆ KOMPUTEROWYCH W PROGRAMACH KSZTAŁCENIA ZINTEGROWANEGO
}

\begin{abstract}
Streszczenie: Stosowanie komputera w nauczaniu zintegrowanym pozwala osiągać lepsze efekty nauczania. Wymaga to jednak zaangażowania i inwencji ze strony nauczyciela. Zajęcia komputerowe w kształceniu zintegrowanym mają na celu rozwijanie umiejętności posługiwania się nowoczesnymi technologiami informacyjno-komunikacyjnymi. Celem niniejszego opracowania była analiza programów nauczania w kształceniu zintegrowanym. Oglądowi poddano cele, treści oraz sugestie dotyczące realizacji zajęć komputerowych i sposobów oceniania. Dlatego też uwzględniono trzynaście wybranych programów prezentowanych na stronie Ośrodka Rozwoju Edukacji.
\end{abstract}

Słowa kluczowe: edukacja zintegrowana, zajęcia komputerowe, cele i treści oraz sposoby oceniania w nauczaniu zintegrowanym

\section{WPROWADZENIE}

Jednym z głównych celów procesu wychowania i nauczania jest przygotowanie uczniów do przyszłego świadomego odbioru i użytkowania współczesnej technologii informacyjnej. Dzięki jej wykorzystaniu można wspomagać i wzbogacać wszechstronny rozwój uczniów, rozwijać ich umiejętności, m.in. w zakresie poszukiwania, porządkowania i wykorzystania informacji z różnych źródeł. „Komputer daje możliwość manipulowania obrazami i przekształcania ich, co wpływa dodatnio dzięki myśleniu konkretno-obrazowemu dziecka w młodszym wieku szkolnym na jego rozwój” (Kłosińska 2010, s. 378). Z drugiej strony w Polsce zaczęto prowadzić 
badania potwierdzające, że zbyt długi czas spędzany przez dziecko m.in. przed komputerem może skutkować zaburzeniami w jego rozwoju poznawczym (Chojak 2015, s. 91; Chojak 2016, s. 231-233).

Tematem niniejszego opracowania jest analiza programów kształcenia zintegrowanego pod kątem celów, treści oraz sugestii dotyczących realizacji zajęć komputerowych i sposobów oceniania, jakie proponują autorzy programów. W badaniach uwzględniono trzynaście wybranych programów prezentowanych na stronie Ośrodka Rozwoju Edukacji, które powstały w ramach projektów konkursowych - konkurs 1/POKL/03.03.04/2013 na opracowanie i pilotażowe wdrożenie innowacyjnych programów nauczania wraz z obudową dydaktyczną (www1). $\mathrm{W}$ badaniach podjęto próbę odpowiedzi na następujące pytania:

- Jakie cele zajęć komputerowych stawiają autorzy programów?

- Jaki jest zakres i układ treści w programach?

- Jakie są sugestie autorów w związku z realizacją programów?

- Jakie są propozycje oceniania ucznia na zajęciach komputerowych?

\section{TECHNOLOGIA INFORMACYJNA A EDUKACJA ZINTEGROWANA}

Konieczność powszechnej edukacji informatycznej wskazywały już od dawna środowiska pedagogiczne, opisując swoje przemyślenia w różnych opracowaniach i raportach. Ma ona ogromne znaczenie dla rozwoju osobowości uczniów, o czym piszą m.in. następujący autorzy: Bronisław Siemieniecki (2003), Janusz Morbitzer, Danuta Morańska, Emilia Musiał (2015), Eunika Baron-Polańczyk (2007), Waldemar Furmanek, Aleksander Piecuch (red.) (2012, 2011), Stanisław Juszczyk (2013, 2015), Kazimierz Wenta, Elżbieta Perzycka (2017).

Konsekwencją wprowadzania zajęć komputerowych jest możliwość pełniejszego poznania przez uczniów podstaw i zastosowań TI oraz przygotowania się do wykorzystywania jej w życiu osobistym, a w przyszłości również zawodowym. Uczeń posługujący się programami komputerowymi ma szansę pogłębiania wiedzy z zakresu wszystkich kierunków kształcenia. Komputer w samodzielnej pracy ucznia spełnia kilka funkcji. Jedną z ważniejszych jest aktywizacja, która wyzwala wielostronne działanie ucznia, pobudzając jego zainteresowania. Wypełnianie funkcji poznawczo-twórczej oznacza, że uczeń ma możliwość rozwiązywania różnorodnych problemów. Samodzielne wykonywanie przez uczniów zadań, które uwzględnia poznane wiadomości i nabyte umiejętności, jest równoznaczne z wypełnianiem funkcji ćwiczeniowej. Niezwykle istotna jest funkcja kontrolna. Przy użyciu komputera można sprawniej zweryfikować działania uczniów. Z kolei realizacja funkcji wychowawczej wiąże się ze stwarzaniem warunków do oddziały- 
wania na osobowość ucznia (wykorzystanie różnych programów komputerowych) w celu usunięcia zaburzeń rozwojowych (Siemieniecki 1998; Janicka-Panek 2011, s. 584-589).

Stosowanie komputera w nauczaniu zintegrowanym daje nieograniczone możliwości. Wymaga to jednak wiele zaangażowania i inwencji ze strony nauczyciela. Jednak by naprawdę mówić o wspomaganiu nauczania komputerem, należy właściwie go obsługiwać oraz mieć możliwość praktycznego wykorzystania w czasie konkretnych zajęć. Przez zastosowanie komputera oddziałujemy na zmysły, co pozwala skutecznie przekazywać treści, aktywizuje i budzi ciekawość. Przekaz multimedialny (muzyka, dźwięk, filmy) przyczynia się do poznawania świata (Ordon, Skoczylas-Krotla 2003). Takie zajęcia są zdecydowanie bardziej efektywne, co potwierdzają badania przeprowadzone przez Danutę Morańską. Wykorzystanie technik multimedialnych na każdym etapie procesu edukacyjnego daje bardzo dobre rezultaty (Morańska 2013). Nie wystarczą jednak specjalne godziny na realizację zajęć komputerowych, gdyż komputer powinno się wykorzystywać w codziennej edukacji, a nie tylko na zajęciach komputerowych.

Nauczanie dzieci w wieku przedszkolnym i wczesnoszkolnym powinno odbywać się przez zabawę. Treści programów edukacyjnych dla najmłodszych dotyczą: języka polskiego, matematyki, przyrody, muzyki, plastyki, informatyki, techniki, języka obcego i innych kierunków edukacji. Komputer daje również możliwość korzystania ze słowników, encyklopedii czy leksykonów. Oprócz programów edukacyjnych zaleca się najmłodszym sięganie po gry strategiczne, stymulacyjne oraz równie często gry z wymagające podejmowania decyzji. Oferta programów komputerowych w klasach I-III jest bardzo bogata i ciekawa (Kłosińska 2002, s. 137-142). Proponowane programy zgodne są z założeniami nauczania zintegrowanego (Kłosińska 2003, s. 168-176). Dzięki nim możemy ćwiczyć spostrzegawczość, koordynację, ale przede wszystkim doskonalić umiejętności, które są niezbędne w procesie nauki szkolnej (Kłosińska 2010, s. 377-387). Stworzone zostały również aplikacje sprawdzające się w nauce czytania oraz w zdobywaniu podstawowej wiedzy z gramatyki i ortografii, rozwijaniu kreatywności (Kłosińska 2014, s. 137-150), a także umożliwiające rozwiązywanie matematycznych łamigłówek. Programy komputerowe można również wykorzystać do rozwijania plastycznych i muzycznych zdolności dziecka. Ponadto dzieci mogą przyswoić podstawowe wiadomości o zapisie muzycznym, poznać muzykę klasyczną, popularną i współczesną. Programy multimedialne i serwisy internetowe dla dzieci mają olbrzymi potencjał edukacyjny: „Wpływają na rozwój osobowości najmłodszych uczniów, ich zainteresowań, pobudzają do twórczego myślenia" (Bednarska 2001, s. 424).

Wprowadzenie programów multimedialnych do nauczania zintegrowanego oznacza wkroczenie nowoczesności do szkoły. Stąd też dynamiczny wzrost liczby 
komputerów w szkolnictwie wszystkich stopni i rodzajów. Możliwe to było między innymi za sprawą pilotażu rządowego programu „Cyfrowa szkoła”, który w ramach modułu „E-szkoła” umożliwiał zakup odpowiedniego sprzętu i oprogramowania zakwalifikowanym placówkom (Czerski, Wawer 2014). Wykorzystanie komputera podczas zajęć wzmacnia zainteresowanie tematem ze strony uczniów, rozwija ich samodzielność, zaś w czasie wolnym pozwala na relaks i ciekawą rozrywkę.

Zastosowanie technologii informacyjnej wpływa na usprawnienie i podniesienie efektywności zajęć zarówno dydaktycznych, jak i wychowawczych oraz terapeutycznych. Nauczyciele muszą się wykazać również kompetencjami informatycznymi. Multimedialne technologie są znaczącą pomocą, a także narzędziem w oddziaływaniach pedagogicznych ze względu na sposoby komunikowania, interaktywność oraz stymulowanie aktywności uczniów. Aby można było je zastosować, potrzebne jest wyposażenie pracowni w sprzęt komputerowy i przygotowanie nauczycieli (Morańska 2002, s. 191-194).

W większości klas szkolnych nie ma miejsca na tradycyjne komputery. Z tego powodu nauczyciele szukają rozwiązań, które umożliwiłyby ich zastąpienie. „Najlepszym rozwiązaniem, patrząc od strony ilości zajmowanego miejsca, byłby zakup laptopów. Przeszkodą jest jednak ich zbyt duża cena za sztukę. Alternatywą dla laptopów będzie ich tańszy odpowiednik, czyli netbook" (Czerski 2009, s. 84).

\section{CELE ZAJĘĆ KOMPUTEROWYCH}

Do najważniejszych umiejętności zdobywanych przez ucznia w trakcie kształcenia ogólnego w szkole podstawowej należą: czytanie, myślenie matematyczne i naukowe, umiejętność komunikowania się w języku ojczystym i w obcym, uczenia się, pracy zespołowej, a także posługiwania się nowoczesnymi technologiami informacyjno-komunikacyjnymi, w tym także dla wyszukiwania i korzystania $\mathrm{z}$ informacji (www2, s. 1-2). Zajęcia komputerowe mają na celu rozwijanie umiejętności posługiwania się nowoczesnymi technologiami informacyjno-komunikacyjnymi.

Tabela 1. Cele zajęć komputerowych

\begin{tabular}{|l|l|}
\hline \multicolumn{1}{|c|}{ Tytuł programu } & \multicolumn{1}{c|}{ Cele } \\
\hline & $\bullet$ kształtowanie umiejętności bezpiecznego posługiwania się komputerem, \\
& tablicą multimedialną, tabletem; \\
Ad@i J@śna matema- & $\bullet$ kształtowanie umiejętności wykorzystywania zasobów internetowych dla \\
tycznejwyspie & własnego rozwoju; \\
& $\bullet$ kształtowanie umiejętności zdobywania informacji za pomocą Internetu; \\
& $\bullet$ poszanowanie dla cudzej pracy i praw autorskich (www3, s. 25).
\end{tabular}




\begin{tabular}{|c|c|}
\hline Tytuł programu & Cele \\
\hline Ciekawi świata & $\begin{array}{l}\text { - rozwijanie umiejętności korzystania z komputera; } \\
\text { - inspirowanie do twórczego wykorzystywania umiejętności pracy na kompu- } \\
\text { terze; } \\
\text { - uświadamianie roli i znaczenia multimediów w codziennym życiu; } \\
\text { - wdrażanie właściwych postaw w zakresie refleksyjnego odbioru reklam } \\
\text { i treści internetowych; } \\
\text { - uświadamianie zagrożeń wynikających z korzystania z komputera, Internetu } \\
\text { i multimediów; } \\
\text { - kształtowanie elementarnej świadomości istnienia praw autorskich; } \\
\text { - wpajanie zasad i umiejętności bezpiecznego korzystania z multimediów } \\
\text { (www4, s. 17-18). }\end{array}$ \\
\hline $\begin{array}{l}\text { Doświadczam - rozu- } \\
\text { miem - wiem }\end{array}$ & $\begin{array}{l}\text { - przygotowywanie czytelnych pod względem graficznym tekstów i obrazów; } \\
\text { - poszukiwanie informacji w Internecie poszerzających zainteresowania i pasje; } \\
\text { - bezpieczne komunikowanie się z innymi ludźmi z poszanowaniem zasad } \\
\text { kultury osobistej; } \\
\text { - projektowanie prostych form użytkowych dostosowanych do aktualnych } \\
\text { potrzeb ucznia (np. listy, plakaty, ogłoszenia, zaproszenia) (www5, s. 28). }\end{array}$ \\
\hline $\begin{array}{l}\text { My bliżej świata. Świat } \\
\text { bliżej nas. }\end{array}$ & $\begin{array}{l}\text { - nabywanie umiejętności zdobywania informacji z różnych źródeł z wykorzy- } \\
\text { staniem technologii komputerowej; } \\
\text { - nabywanie umiejętności poszukiwania informacji naukowych; } \\
\text { - tworzenie prostych animacji, praca na komputerze z wykorzystaniem aplika- } \\
\text { cji, programów, zasobów Internetu; } \\
\text { - korzystanie z komputera do odczytywania informacji przekazywanych w po- } \\
\text { staci filmu, animacji, prezentacji, programów multimedialnych itp. (www5, } \\
\text { s. 10) }\end{array}$ \\
\hline $\begin{array}{l}\text { Myśle - działam-idę } \\
w \text { świat }\end{array}$ & $\begin{array}{l}\text { Uczeń: } \\
\text { - wykorzystuje zasoby multimedialne do własnego rozwoju; } \\
\text { - przyjmuje postawę refleksyjnego odbioru treści internetowych; } \\
\text { - poszukuje, gromadzi, przetwarza informacje, wykorzystuje je po dokonaniu } \\
\text { ich krytycznej oceny; } \\
\text { - twórczo wykorzystuje umiejętności pracy na komputerze; } \\
\text { - posiada wiedzę i umiejętności w zakresie bezpiecznego korzystania z kompu- } \\
\text { tera, Internetu i multimediów; } \\
\text { - jest świadomy tego, że obsługa komputera jest przydatna w życiu, ułatwia } \\
\text { sposób porozumiewania się między ludźmi (www6, s. 8). }\end{array}$ \\
\hline
\end{tabular}

W tabeli 1 przedstawione zostały najbardziej charakterystyczne cele zajęć komputerowych. Dostrzegamy duże zróżnicowanie w ich formułowaniu. Dotyczą one różnych aspektów pracy z komputerem. Najbardziej uszczegółowione zostały w programie Myślę - działam - idęwświat, najmniej w programie Ad@i J@śna matematycznej wyspie. 


\section{TREŚCI EDUKACJI KOMPUTEROWEJ}

Zgodnie z podstawą programową w toku zajęć komputerowych uczeń:

1) posługuje się komputerem w podstawowym zakresie;

2) posługuje się wybranymi programami i grami edukacyjnymi, rozwijając swoje zainteresowania; korzysta $z$ opcji w programach;

3) wyszukuje informacje i korzysta $z$ nich:

a) przegląda wybrane przez nauczyciela strony internetowe (np. stronę swojej szkoły),

b) dostrzega elementy aktywne na stronie internetowej, nawiguje po stronach w określonym zakresie,

c) odtwarza animacje i prezentacje multimedialne;

4) tworzy teksty i rysunki:

a) wpisuje za pomocą klawiatury litery, cyfry i inne znaki, wyrazy i zdania,

b) wykonuje rysunki za pomocą wybranego edytora grafiki,np.zgotowych figur;

5) zna zagrożenia wynikające z korzystania z komputera, Internetu i multimediów:

a) wie, że praca przy komputerze męczy wzrok, nadweręża kręgosłup, ogranicza kontakty społeczne; wie, jak trzeba korzystać z komputera, żeby nie narażać własnego zdrowia,

b) ma świadomość niebezpieczeństw wynikających $\mathrm{z}$ anonimowości kontaktów i podawania swojego adresu,

c) stosuje się do ograniczeń dotyczących korzystania z komputera, Internetu i multimediów (www2, s. 13-14; www7, s. 42).

Zgodnie z podstawą w programach najczęściej w zakresie zajęć komputerowych wyodrębniane są takie działy, jak: znajomość komputera, wyszukiwanie i korzystanie z informacji, tworzenie tekstów i rysunków, zagrożenia wynikające z korzystania z komputera, Internetu i programów multimedialnych (www6, s. 18-19) lub np. bezpieczeństwo i higiena pracy z komputerem, obsługa komputera i oprogramowania, wykorzystanie możliwości, jakie daje posługiwanie się komputerem (www8, s. 65).

W programie Ciekawi świata szczegółowo przedstawione zostały treści i przyporządkowane im efekty kształcenia z zakresu zajęć komputerowych. W odniesieniu do treści wyodrębniono:

1) Posługiwanie się komputerem: poznanie elementów zestawu komputera; posługiwanie się myszką, klawiaturą; uruchamianie i wyłączanie komputera; poznanie i rozumienie pojęć: pulpit, plik, folder; uruchamianie stacji dysków CD; otwieranie i zamykanie programów. 
2) Posługiwanie się wybranymi programami i grami edukacyjnymi:

a) znajomość wybranego edytora graficznego (np.: Point, PowerPoint, Painter Classic);

- przeznaczenie programu;

- budowa okna programu;

- rodzaje pędzli w edytorze graficznym;

- rodzaj narzędzi malarskich;

- projektowanie prac graficznych;

b) poznanie zasad pracy z edytorem tekstu Word;

- poznanie działania klawiszy: Spacja, Enter, Caps Lock, Shift, Backspace;

- zasady pisania za pomocą klawiatury liter: a, e, ż, ź;

- zasady pisania znaków interpunkcyjnych;

- pisanie prostych tekstów według wskazówek;

- stosowanie różnych stylów, rozmiarów i kolorów czcionek;

- stosowanie narzędzi numerowania;

- kopiowanie, wklejanie, wycinanie tekstu;

c) gry edukacyjne;

- uruchamianie, zamykanie gier edukacyjnych;

- korzystanie z gier komputerowych;

- posługiwanie się kursorem i myszką.

3) Wyszukiwanie informacji w Internecie:

a) przeglądanie wybranych stron WWW;

b) gromadzenie informacji na wskazany temat;

c) przestrzeganie praw autorskich;

d) odtwarzanie animacji i prezentacji multimedialnych.

4) Korzystanie $z$ poczty elektronicznej.

5) Poznanie i stosowanie zasad bezpieczeństwa wynikających z korzystania z komputera, Internetu, multimediów:

a) zasady pracy przy komputerze;

b) zagrożenia zdrowotne;

c) zagrożenia społeczne (www4, s. 52-54).

Szczegółowy wykaz treści z podziałem na klasy występuje w programie Mały wynalazca (www9, s. 55-56), Innowacje gwarancja skutecznej edukacji (www10, s. 33-34), Ad@i J@śna matematycznejwyspie (www3, s. 39-40), podobnie w programie Zosia i Staś w szkole (www11, s. 42-43; www16), w którym zaproponowano także treści rozszerzające. W programie Nowoczesny świat, nowoczesna szkoła treści zaprezentowane są za pomocą tabeli, zostały też podane osiągnięcia ucznia podstawowe i ponadpodstawowe po klasie I i III. Ukazano możliwości integracji 
treści z zakresu edukacji przyrodniczej z językiem angielskim oraz rozwijania wielorakich inteligencji dzieci (www8, s. 39, 65).

W ujęciu całościowym, bez podziału na klasy, przedstawiono treści w programie Trampolina do sukcesu (www12, s. 27), Myśle - działam - idę w świat (www6, s. 19), Ciekawi świata (www4, s. 52-54), Doświadczam - rozumiem - wiem (www13, s. 81-84), My bliżej świata. Świat bliżej nas (www5, s. 30-31), Szkoła przyszłości (www14, s. 19), Obywatel świata (www15, s. 33), Twórcze umysły (www7, s. 41).

W programie Doświadczam - rozumiem - wiem oprócz treści i osiągnięć opisano także kompetencje, które uczeń rozwija w toku zajęć komputerowych. Są to kompetencje: informatyczne, komunikacyjne, artystyczne, społeczne, emocjonalne i interpersonalne oraz myślenie twórcze (www13, s. 82-84).

\section{REALIZACJA PROGRAMU}

Autorzy podstawy programowej zalecają, aby:

zajęcia komputerowe rozumieć dosłownie jako zajęcia z komputerami, prowadzone w korelacji z pozostałymi obszarami edukacji. Nie oznacza to jednak rezygnacji z metod nauczania zakładających prezentowanie poprzez zabawę i w sposób prosty działania urząazeń komputerowych bez ich wykorzystania. Należy zadbać o to, aby w sali lekcyjnej było kilka kompletnych zestawów komputerowych z oprogramowaniem odpowiednim do wieku, możliwości i potrzeb uczniów. Komputery w klasach I-III szkoły podstawowej są wykorzystywane jako urządzenia, które wzbogacają proces nauczania i uczenia się o teksty, rysunki i animacje tworzone przez uczniów, kształtują ich aktywność (gry i zabawy, w tym zabawy logiczne, mogące być wstępem do nauki programowania), utrwalają umiejętności (programy edukacyjne na płytach i w sieci), rozwijają zainteresowania itp. Uczniom klas I-III należy umożliwić korzystanie ze szkolnej pracowni komputerowej. Zaleca się, aby podczas zajęć uczeń miał do swojej dyspozycji osobny komputer z dostępem do Internetu (www2, s. 22; www12, s. 18).

W cyklu trzyletnim proponuje się 95 godzin zajęć komputerowych, tj. 1 godzinę tygodniowo w każdej klasie. W celu wyrównania szans uczniów pochodzących $\mathrm{z}$ różnych środowisk $\mathrm{w}$ dostępie do nowoczesnych technologii i zapobiegnięcia analfabetyzmowi funkcjonalnemuw programie Ad@i J@ś na matematycznej wyspie sugeruje się, aby nauczyciele i uczniowie korzystali często z komputera, tabletów z dostępem do Internetu oraz pomocy multimedialnych zgromadzonych na stronie www.matematycznawyspa.pl, przeznaczonych bezpośrednio do realizacji założeń programu (www3, s. 13). 
W programie Innowacje gwarancją skutecznej edukacji proponuje się realizację wszystkich kierunków edukacji z zastosowaniem narzędzi TIK, wymieniając korzyści, jakie czerpie nauczyciel i uczeń z tego typu zajęć.

Tabela 2. Korzyści płynące ze stosowania TIK w edukacji wczesnoszkolnej (www10, s. 65)

\begin{tabular}{|c|c|}
\hline Korzyści po stronie nauczyciela & Korzyści po stronie uczniów \\
\hline $\begin{array}{l}\text { a) przygotowanie warsztatu pracy - } \\
\text { obudowa multimedialna, zasoby } \\
\text { Internetu, } \\
\text { b) dokumentowanie pracy ucznia - } \\
\text { filmy, zdjęcia, nagrania stworzone } \\
\text { w ramach projektów edukacyjnych, } \\
\text { c) ocenianie i ewaluacja, } \\
\text { d) stosowanie różnych form prze- } \\
\text { kazu treści - multimedialne gry, } \\
\text { animacje, ćwiczenia interaktywne, } \\
\text { programy komputerowe, edytory } \\
\text { tekstów, zasoby Internetu, GPS, } \\
\text { kamera, telefon komórkowy, MP3, } \\
\text { MP4, } \\
\text { e) uatrakcyjnienie procesu dydak- } \\
\text { tycznego, } \\
\text { f) poszerzenie oferty dydaktycznej } \\
\text { szkoły, } \\
\text { g) alternatywa tradycyjnych narzędzi } \\
\text { placówki edukacyjnej. }\end{array}$ & $\begin{array}{l}\text { a) ćwiczenie małej motoryki - obsługa ekranu dotykowego, } \\
\text { klawiatury, } \\
\text { b) powiązanie zagadnień matematycznych z innymi dziedzina- } \\
\text { mi nauki - ćwiczenia interaktywne, gry multimedialne, } \\
\text { c) nauka orientacji na płaszczyźnie - ćwiczenia interaktywne, } \\
\text { gry multimedialne, zasoby Internetu, } \\
\text { d) rozwijanie aktywności poznawczej - multimedialne gry, } \\
\text { animacje, ćwiczenia interaktywne, programy komputerowe, } \\
\text { edytory tekstów, zasoby Internetu, GPS, kamera, telefon } \\
\text { komórkowy, MP 3, MP 4, } \\
\text { e) wizualizowanie nieznanych pojęć - filmy, prezentacje multi- } \\
\text { medialne, animacje, } \\
\text { f) pozyskiwanie informacji z różnych źródeł - zasoby Internetu, } \\
\text { pozyskiwanie informacji za pomocą nagrań audio i video, } \\
\text { rejestracja efektów pracy podczas projektów edukacyjnych, } \\
\text { g) praca w grupie - gry multimedialne, } \\
\text { h) nadążanie za postępem technologicznym, } \\
\text { i) przeciwdziałanie wykluczeniu technologicznemu - dostęp- } \\
\text { ność narzędzi TIK w czasie zajęć dydaktycznych. }\end{array}$ \\
\hline
\end{tabular}

Autorzy programu Doświadczam - rozumiem - wiem są zdania, że korzystanie z nowoczesnych technologii stanowi kompetencję kluczową. Aplikacje, edytory tekstu, grafiki, przeglądarki i wyszukiwarki internetowe traktują jako narzędzia do poszerzenia wiedzy i umiejętności w jakiejś dziedzinie. W ich opinii zajęcia komputerowe w pierwszym etapie edukacyjnym nie powinny być oderwane od pozostałych treści nauczania, lecz traktowane jako naturalne uzupełnienie ich (ćwiczenia w ramach nauki języka obcego, zadania matematyczne, albumu przyrodnicze online, słowniki języka polskiego, lektury online, audiobooki). Takie podejście wymaga oczywiście odpowiedniego przygotowania technicznego uczniów w ramach początkowych zajęć w pierwszej klasie, zwrócenia szczególnej uwagi na zróżnicowany poziom uczniów w zakresie umiejętności obsługi komputerów (uwarunkowania środowiskowe, w tym nierówności społeczne) (www13, s. 29).

W programie Innowacje gwarancja skutecznej edukacji podkreśla się, że różne gry i zabawy współczesne dzieci porzuciły dla tych komputerowych, a „surfowanie w sieci” idzie im czasami lepiej niż jazda na rowerze. 
Mamy oczywiście obowiązek czuwać, by życie wirtualne nie zastąpiło im realnego, ale powinniśmy jako rodzice i nauczyciele wykorzystać miłość do komputera i możliwości przez niego stwarzanych, aby wprowadzić nasze dzieci i uczniów w dorosłość we współczesnym świecie, do której droga prowadzi przede wszystkim przez edukację (www10, s. 3).

Postęp w dziedzinie nowych technologii informatycznych zrewolucjonizował naszą cywilizację. Komputery i inne urządzenia nowej technologii są wszechobecne w codziennym życiu i posługuje się nimi wiele dzieci. Szkoła może wyposażyć uczniów w umiejętność właściwego korzystania z TIK, a to pozwoli na rozwój dzieci, ich zainteresowań. Komputery, laptopy, smartfony są obecnie urządzeniami, które mogą zastąpić książkę, telewizję, odtwarzacz obrazu i dźwięku. Internet z kolei to międzynarodowy system wymiany informacji pozwalający rozwijać zainteresowania, kontakty interpersonalne, poznawać inne kultury.

Zadaniem nauczyciela jest nauczenie takiego korzystania z TIK, aby dzieci umiały:

- korzystać z nich bezpiecznie,

- odróżnić świat realny od świata cyfrowego,

- porównać informacje i programy,

- poznać ogólnoświatowy język symboli (tamże, s. 3).

A oto przykłady proponowanych działań innowacyjnych w zakresie TIK:

a) filmy edukacyjne z zasobów Internetu do przekazywania treści podstaw przedsiębiorczości, przyrodniczych, społecznych,

b) ćwiczenia interaktywne mają na celu indywidualizację, ułatwienie rozumienia treści nauczania, aktywizację i funkcjonalność stosowania w dowolnym momencie zajęć. Proponowane ćwiczenia dotyczą: klasyfikowania zbiorów, porównywania elementów, rozpoznawania figur geometrycznych, dokonywania obliczeń matematycznych w zakresie czterech działań, wskazań zegara i obliczeń zegarowych. Są one skorelowane $\mathrm{z}$ treściami innych edukacji, np. szeregowanie dzieci wg wzrostu, rozdzielanie przyborów szkolnych między dziećmi, odszyfrowywanie haseł poprzez działania matematyczne,

c) prezentacje multimedialne służą uprzystępnieniu treści, rozwijaniu umiejętności, dostrzegania następstwa czasowego, stanowią wstęp do treści wykorzystywanych w edukacji matematycznej oraz podstaw przedsiębiorczości, np. prezentacje o segregowaniu śmieci, posługiwaniu się tabelą liczbową, o banku, o rozkładzie jazdy,

d) animacje komputerowe służą wizualizacji treści, stanowią wstęp do treści z różnych edukacji, np. animacja o locie w kosmos, system dziesiętny,

e) multimedialne gry edukacyjne ćwiczą pamięć, uczą przestrzegania reguł, zasad zdrowej rywalizacji, uczą ograniczeń czasowych, w osobliwy sposób łączą technikę rachunkową $\mathrm{z}$ treściami z pozostałych edukacji, 
f) multimedialne gry, łamigłówki, zagadki rozwijają logiczne myślenie. Są to szyfry, rebusy, labirynty, gry typu memo, gry planszowe, kolorowanki matematyczne, puzzle, łączące edukację matematyczną z polonistyczną, przyrodniczą,

g) strony internetowe i programy z zasobami matematycznymi służą wzmacnianiu motywacji, budują wiarę w siebie, pozwalają osiągnąć sukces, np. matzoo, $2+2$,

h) proste programy graficzne wykorzystywane w czasie zajęć komputerowych oraz projektów edukacyjnych, np. Paint, Mały Malarz, rozwijające kreatywność, wyobraźnię, wspomagają edukację matematyczną,

i) korzystanie z nowoczesnych urządzeń elektronicznych: komputer, tablet, telefon komórkowy, pendrive, aparat cyfrowy, dyktafon, odtwarzacze MP3 i MP4, GPS, służące zajęciom ruchowym, muzycznym,

j) komunikatory służące budowaniu relacji społecznych, np. Gadu-Gadu, Skype (tamże, s. 67).

Autorzy programu proponują nauczycielom samodzielne tworzenie zasobów edukacyjnych. Zalecają skorzystanie z listy linków lub stworzenie własnej bazy takich narzędzi. Dzięki temu nauczyciel będzie mógł wykorzystać dodatkowe materiały na lekcje lub stworzyć je samodzielnie, dostosowując je do potrzeb uczniów i warunków nauczania.

A oto proponowana lista linków:

- www.didakta.pl (programy i gry on-line oraz ćwiczenia on-line)

- www.edu.tvp.pl (nagrania, prezentacje, filmy, programy telewizyjne)

- www.ninateka.pl (baza materiałów)

- www.scholaris.pl (portal z zasobami edukacyjnymi)

- http://gry-dladziewczyn.pl/gry-matematyczne/ (gry dla dzieci)

- www.matzoo.pl (gry i ćwiczenia matematyczne)

- www.matmag.pl (platforma e-lerningowa do matematyki)

- http://gry-dladzieci.pl/gry-edukacyjne/ (gry matematyczne; gry ekologiczne)

- http://ciufcia.pl/ (gry dla dzieci)

- http://www.abecadlo.cauchy.pl (zagadki, łamigłówki)

- www.matematyka.net

- http://wirtualnykraj.pl/

- www.klasoteka.pl (gry edukacyjne dla dzieci)

- http://smartygames.com (gry edukacyjne w języku angielskim)

- http://www.gry.jeja.pl/ (różne rodzaje gier, w tym także matematyczne)

- http://ekodzieciaki.mos.gov.pl (gry w temacie ekologii) (tamże). 
Oryginalne rozwiązania w związku z edukacją komputerową zaproponowano także w programie Myślę - działam - idę wświat, w którym preferuje się wykorzystanie technologii informacyjno-komunikacyjnej przez: tworzenie multimedialnych plakatów, prowadzenie bloga, przygotowywanie przez uczniów multimedialnych materiałów, tj. prezentacji, filmików czy komiksów (www6, s. 120). W programie tym uwzględnia się WebQuest - nowatorską metodę pracy z uczniami wykorzystującą technologię informacyjną. Celem tej metody jest budowanie własnej wiedzy dzięki wykorzystaniu Internetu w toku uczenia się zespołowego opartego na idei konstruktywizmu. Według Berniego Dodge’a, twórcy koncepcji WebQuestu, większość lub całość informacji uzyskanych przez uczących się pochodzi z Internetu. WebQuest wykorzystuje zainteresowanie uczniów komputerem i Internetem, uczy przemyślanego i konstruktywnego korzystania z jego zasobów. Pokazuje, że wirtualna sieć może być narzędziem pracy, a nie wyłącznie rozrywki. Zadaniem nauczyciela jest dobór materiału źródłowego, który ma pozwolić uczniom bardziej skupić się na krytycznej analizie i użyciu informacji niż na ich szukaniu w Internecie. WebQuest może być projektem w ramach jednej dyscypliny, ale może mieć też charakter interdyscyplinarny. Może być krótkoterminowy (1-2 godziny lekcyjne) lub długoterminowy (kilka tygodni). Produktem finalnym może być plakat, praca pisemna, prezentacja multimedialna, wystąpienie publiczne itp. (tamże, s. 62).

\section{OCENIANIE AKTYWNOŚCI UCZNIÓW}

W program Myślę, działam, idę wświat zaproponowano ocenę wiadomości i umiejętności uczniów na kilku poziomach:

Poziom najwyższy: Sprawnie posługuje się komputerem w podstawowym zakresie: wypisuje za pomocą klawiatury litery, cyfry i inne znaki, wyrazy i zdania, doskonale zna zagrożenia wynikające z korzystania z komputera, Internetu i multimediów, samodzielnie posługuje się programami i grami edukacyjnymi, odtwarza animacje i prezentacje multimedialne, nawiguje po stronach w określonym zakresie, przegląda wybrane przez nauczyciela strony internetowe (np. stronę swojej szkoły), wykonuje rysunki za pomocą wybranego edytora grafiki, np. z gotowych figur.

Poziom bardzo wysoki: Sprawnie posługuje się komputerem w podstawowym zakresie: tworzy proste dokumenty tekstowe - wpisuje za pomocą klawiatury litery, cyfry i inne znaki, zna zagrożenia wynikające z korzystania z komputera, Internetu i multimediów, posługuje się programami i grami edukacyjnymi, odtwarza animacje i prezentacje multimedialne, nawiguje po stronach w określonym zakresie, przegląda 
wybrane przez nauczyciela strony internetowe (np. stronę swojej szkoły), wykonuje rysunki za pomocą wybranego edytora grafiki.

Poziom wysoki: Posługuje się komputerem w podstawowym zakresie: tworzy proste dokumenty tekstowe za pomocą klawiatury (litery, cyfry i inne znaki), podaje przykłady zagrożeń wynikających z nieprawidłowego korzystania z komputera, wie, że korzystając z Internetu, nie należy podawać swoich danych, posługuje się prostymi programami i grami edukacyjnymi, odtwarza animacje i prezentacje multimedialne, wyszukuje podane strony internetowe, potrafi wpisać adres strony internetowej i wyszukać potrzebne informacje, wykonuje proste rysunki za pomocą wybranego edytora grafiki.

Poziom średni: Potrafi posługiwać się komputerem (myszką, klawiaturą, włączyć i wyłączyć komputer), zapisuje za pomocą klawiatury litery, cyfry i inne znaki, wykonuje proste rysunki za pomocą wybranego edytora tekstu, pod kierunkiem nauczyciela posługuje się prostymi programami i grami edukacyjnymi, przegląda strony internetowe o podanym przez nauczyciela adresie, zna zagrożenia wynikające z korzystania z komputera, Internetu i multimediów (wie, że praca przy komputerze męczy wzrok, nadweręża kręgosłup, ogranicza kontakty społeczne, ma świadomość niebezpieczeństw wynikających z anonimowości kontaktów i podawania swojego adresu).

Poziom niżej średni: Posługuje się komputerem w podstawowym zakresie, nie $\mathrm{w}$ pełni rozumie zagrożenia dla zdrowia wynikające $\mathrm{z}$ nieprawidłowego korzystania z komputera, popełnia błędy, korzystając z klawiatury (litery, cyfry i inne znaki), z pomocą nauczyciela wykonuje proste rysunki, korzystając z edytora grafiki, pod kierunkiem nauczyciela posługuje się prostymi programami i grami edukacyjnymi, z pomocą nauczyciela przegląda strony internetowe o podanym adresie, nie zawsze świadomie korzysta z Internetu.

Poziom niski: Posługuje się myszką i klawiaturą, nie rozumie zagrożeń dla zdrowia wynikających z nieprawidłowego korzystania z komputera, nie opanował podstawowych umiejętności korzystania z edytora grafiki, tworzenia dokumentów tekstowych i samodzielnego korzystania z programów i gier (tamże, s. 162-163).

\section{PODSUMOWANIE}

Analiza programów pozwala stwierdzić, że są one bardzo zróżnicowane w przypadku zajęć komputerowych. Niektóre z nich, np.: Myślę-działam-idęw świat czy Innowacje gwarancja skutecznej edukacji, szczegółowo instruują nauczycieli, jak realizować zajęcia komputerowe, podkreślając rolę TIK w integrowaniu wiedzy i samodzielnym uczeniu się. Inne zaś mniej miejsca poświęcają tym zajęciom. O ich „mniejszej” randze świadczy, naszym zdaniem, także nazewnictwo użyte 
w podstawie programowej, w której wszystkie inne treści skupione są wokół kierunków edukacji (polonistycznej, matematycznej, muzycznej itp.). Nie jest jasne zatem, dlaczego zajęcia te nie zostały nazwane np. edukacją medialną, skoro taki termin pojawia się w leksykonie pedagogiki, w którym jest on zdefiniowany jako:

dziedzina kształcenia o charakterze interdyscyplinarnym, traktująca o roli środków masowego przekazu w procesie socjalizacji, uczenia się i wychowania, przygotowując osoby do sprawnego przekazywania informacji za pośrednictwem nowych technologii, kształcąca kompetencje do posługiwania się elektronicznymi multimediami oraz przygotowująca do krytycznego odczytywania znaczeń kultury wizualnej. Celem jest przygotowanie uczących się od aktywnego i odpowiedzialnego życia w społeczeństwie informacyjnym (Milerski, Śliwerski 2000, s. 55).

I taka, naszym zdaniem, jest istota tych zajęć.

\section{LITERATURA}

Baron-Polańczyk E., 2007, Multimedialne materiały dydaktyczne w edukacji technicznoinformatycznej w szkole podstawowej i gimnazjum. Raport z badań. Zielona Góra, Oficyna Wydawnicza Uniwersytetu Zielonogórskiego.

Bednarska E., 2001, Komputer w życiu dziecka. „Życie Szkoły”, nr 7.

Chojak M., 2015, Nowe technologie a rozwój wybranych procesów poznawczych u dzieci w wieku przedszkolnym i wczesnoszkolnym. W: K. Denek, A. Kamińska, P. Oleśniewicz (red.), Edukacja jutra. Nowe technologie w kształceniu. Sosnowiec, Wyższa Szkoła HUMANITAS.

Chojak M., 2016, Nadmierny kontakt z mediami, jako przyczyna zaburzeń rozwoju poznawczego dzieci kończacych wychowanie przedszkolne - raport z badań. W: A. Kamińska. P. Oleśniewicz (red.), Edukacja jutra. Aspekty wychowania i kształcenia we współczesnej szkole. Sosnowiec, Wyższa Szkoła HUMANITAS.

Czerski W., 2009, Netbooki przyszłościa dla szkolnych pracowni w szkole podstawowej XXI wieku. W: W. Lib, W. Walat (red.), Edukacja - Technika - Informatyka. Teoretyczne i praktyczne problemy edukacji informatycznej i informacyjnej. Rzeszów, Wydawnictwo Uniwersytetu Rzeszowskiego.

Czerski W., Wawer R., 2014, „Cyfrowa szkoła” - szansa czy zagrożenie dla edukacji?. „Dydaktyka Informatyki”, nr 9.

Furmanek W., Piecuch A. (red.), 2011, „Dydaktyka informatyki”, nr 6: Problemy i wyzwania społeczeństwa informacyjnego. Rzeszów, Wydawnictwo Uniwersytetu Rzeszowskiego. 
Furmanek W., Piecuch A. (red.), 2012, „Dydaktyka Informatyki”, nr 7: Problemy efektywności informatycznej technologii informacyjnych i multimedialnych $w$ edukacji. Rzeszów, Wydawnictwo Uniwersytetu Rzeszowskiego.

Janicka-Panek T., 2011, Konstruktywistyczna perspektywa wychowania współczesnego dziecka w wieku 6-11 lat. W: Rozwój pedagogicznych naukw Ukrainie i Polsce na poczatku XXI stulecia. Czerkasy, 584-589.

Juszczyk S. i in., 2003, Dydaktyka informatyki i technologii informacyjnej. Toruń, Wydawnictwo Adam Marszałek.

Juszczyk S., 2005, Konstruktywistyczne i kognitywistyczne koncepcje nauczania wspomaganego komputerem oraz uczenia się z wykorzystaniem Internetu. „Pedagogika Mediów", nr 1.

Kłosińska T., 2002, Edukacyjne programy multimedialne $w$ kształceniu wczesnoszkolnym. „Życie Szkoły”, nr 3.

Kłosińska T., 2003, Zastosowanie programów multimedialnych w edukacji wczesnoszkolnej. W: J. Kuźma, J. Morbitzer (red.), Nauki pedagogiczne w teorii i praktyce edukacyjnej, t. II. Kraków, Wydawnictwo Naukowe Akademii Pedagogicznej.

Kłosińska T., 2010, Programy multimedialne pomoca we wczesnej terapii dziecka. W: E. Marek, J. Łuczak (red.), Diagnoza i terapia psychopedagogiczna w edukacji dziecka. Piotrków Trybunalski, Naukowe Wydawnictwo Piotrkowskie przy Filii Uniwersytetu Humanistyczno-Przyrodniczego Jana Kochanowskiego.

Kłosińska T., 2014, Uczeń przed komputerem. Kreatywność polonistyczna dziecka. W: H. Krauze-Sikorska, M. Klichowski, A. Basińska (red.), Children in the Postmodern World. Culture - Media - Social Inequality. Poznań, Wydawnictwo Naukowe Uniwersytetu im. Adama Mickiewicza.

Milerski, B. Śliwerski B. (red.), 2000, Pedagogika. Leksykon. Warszawa, Wydawnictwo Naukowe PWN.

Morańska D., 2013, Zastosowanie netbooków w klasach I-III a efekty kształcenia. W: J. Morbitzer, E. Musiał (red.), Człowiek - Media - Edukacja. Kraków, Katedra Technologii i Mediów Edukacyjnych. Uniwersytet Pedagogiczny im. KEN.

Morbitzer J., Morańska D., Musiał E., 2015, Człowiek, media, edukacja. Dąbrowa Górnicza, Wydawnictwo Naukowe, Wyższa Szkoła Biznesu.

Ordon U., Skoczylas-Krotla E., 2003, Środki masowego przekazu - szansą czy zagrożeniem w procesie edukacji dziecka. W: T. Banaszkiewicz, W. Szlufik, A. Pękala (red.), Z najnowszych badań nad wczesną edukacja dziecka. Częstochowa, Wydawnictwo Wyższej Szkoły Pedagogicznej.

Siemieniecki B., 1998, Komputer $w$ diagnostyce i terapii pedagogicznej. Toruń, Wydawnictwo Adam Marszałek.

Siemieniecki B., 2003, Technologia informacyjna w polskiej szkole. Stan i zadania. Toruń, Wydawnictwo Adam Marszałek. 
Wenta K., Perzycka E. (red.), 2007, Edukacja informacyjna. Neomedia w dydaktyce i działaniach wychowawczo-opiekuńczych. Szczecin, Zapol.

\section{NETOGRAFIA}

wwwl: http://www.ore.edu.pl/edukacja-najmlodszych/4291-programy-nauczaniaedukacja-wczesnoszkolna \{dostęp: 15.09.2015]..

www2: Podstawa programowa kształcenia ogólnego dla szkół podstawowych. I etap edukacji: klasy I-III. Edukacja wczesnoszkolna, opublikowano: https://men.gov. pl/wp-content/uploads/2014/08/zalacznik_2.pdf_[dostęp: 15.09.2015]

www3: Bogacka J., Dobosz A., Ilnicka E., Krasowska-Żmurko M., Krauze M., Krawiec E.,Ad@iJ@śna matematycznejwyspie, opublikowano: http://matematycznawyspa. pl/uploads/files/dla_nauczyciela/program_nauczania_recenzje/program_nauczania_Ada\%20i\%20Jas\%20na\%20matematycznej\%20wyspie_z\%20poprawkami_25_03_2015.pdf [dostęp: 15.09.2015].

www4: Czerkas J., Woś A., Ciekawi świata, opublikowano: http://innowacja.sfera. lublin.pl/materialy/program_nauczania.pdf [dostęp: 15.09.2015].

www5: Goliszek B., Małecka-Perszko B., My bliżej świata. Świat bliżej nas, opublikowano: http://my-blizej-swiata.com.pl/swiat-blizej-nas/files/Program-Innowacyjny-My-bli-ej--wiata----wiat-bli-ej-nas.pdf [dostęp: 15.09.2015].

www6: Dziadkiewicz A., Florczak A., Gąsior D. i inni., Myślę-działam-idę w świat, opublikowano: http://projekt.noweskalmierzyce.pl/wp-content/uploads/2015/ PROGRAM-NAUCZANIA-WCZESNOSZKOLNEGO-Z-J\%C4\%98ZYKIEMANGIELSKIM.pdf [dostęp: 15.09.2015].

www7: Knopik M., Twórcze umysły. Edukacja ku kreatywności, opublikowano: http:// sawg.pl/upload/upload/maly\%20czlowiek\%20materialy\%20www/Program\%20 nauczania\%20dla\%20klasy\%20I-III.pdf [dostęp: 15.09.2015].

www8: Bigus-Franczuk N., Sokal K., Nowoczesny świat, nowoczesna szkoła, opublikowano: http://www.nowoczesnaszkola.com.pl/themes/ipn/assets/innowacyjny_program_nauczania.pdf [dostęp 15.09.2015].

www9: Krukowska A., Stelmach S. i in., Mały wynalazca, opublikowano: http://mais. wspkorczak.eu/wp-content/uploads/2015/07/Maly_Wynalazca-popr.pdf [dostęp: 15.09.2015].

www10: Innowacje gwarancja skutecznej edukacji, opublikowano: http://igse.portaledu.pl/doc/Program_Nauczania_IGSE.pdf [dostęp: 15.09.2015].

www11: Wróblewska M., Potręć M., Małachowska K. i inni, Staś i Zosia w szkole, opublikowano: http://stasizosia.info/wp- content/uploads/2015/01/Innowacyjny_ program_po_erracie_poprawki.pdf [dostęp: 15.09.2015]. 
www12: Kiedrowicz D., Szołkowska M., Szydziak B. i inni, Trampolina do sukcesu, opublikowano: http://landers.pl/assets/Program-nauczania-TRAMPOLINA-DOSUKCESU-z-dn-24_06_2015.pdf [dostęp 15.09.2015].

www13: Domagała-Zyśk E., Knopik M., Knopik T., Kucharska B., Doświadczam - rozumiem - wiem, opublikowano: http://drw.lechaa.pl/wp-content/uploads/2015/08/ Do\%C5\%9Bwiadczam_rozumiem_wiem-program_nauczania_red3.pdf [dostęp 15.09.2015].

www14: Duszyńska G., Szymańska I., Szkoła przyszłości, opublikowano: http://szkolaprzyszlosci.strefa-klienta.net/ [dostęp: 15.09.2015].

www15: Przybylska J., Stępień Z., Obywatel świata, opublikowano: http://mais.wspkorczak.eu/programy-nauczania/ [dostęp: 15.09.2015]. wwwl6: http://www.ceo.org.pl/pl/ok [dostęp: 15.09.2015].

\title{
PEDAGOGICAL INTERPRETATION OF ICT CLASSES IN THE CURRICULA OF INTEGRATED EDUCATION
}

\begin{abstract}
Using a computer in the process of integrated education offers great possibilities in achieving the effects of teaching. It requires, though, a teacher's commitment and invention. ICT classes in integrated education aim at developing the abilities of using modern information- communication technology. The purpose of the research was to analyze the curricula in integrated education. The aims, content and suggestions regarding ICT classes and ways of assessing knowledge have been analyzed. In order to achieve the aim, thirteen chosen curricula presented on the website of the Centre for Education Development have been taken into account.
\end{abstract}

Keywords: integrated education, ICT classes, aims, content and ways of assessing in integrated education 